\title{
New Findings of Flowering Plants \\ in the Angaro-Chunsky Interfluve (the Krasnoyarsk Krai) (2)
}

\author{
Filipp S. Yuzefovich* and Natalia N. Tupitsyna \\ V.P. Astafyev Krasnoyarsk State Pedagogical University \\ 89 Ada Lebedeva Str., Krasnoyarsk, 660049, Russia
}

Received 04.10.2017, received in revised form 25.04.2018, accepted 11.07.2018, published online 11.10.2018

The Angaro-Chunsky interfluve (the Boguchansky District of the Krasnoyarsk Krai) is a remote and insufficiently floristically studied area located in the southern taiga subzone of Middle Siberia at the boundary of three floristic provinces (the Altai-Yenisei oro-hemiboreal, Tunguska-Lena boreal, and Baikal hemiboreal provinces), having an area of about $20000 \mathrm{~km}^{2}$. The northern boundary of the study area is the left bank of the Angara River, the southern one is the right bank of the Chuna River, and the western and the eastern boundaries coincide with the administrative boundary of the Boguchansky District. As economic activities in the region lead to increasing human impact and fires, the state of the vegetation should be closely monitored. Thus, the purpose of the present study is to determine the composition, structure, and characteristics of the flora in the Angaro-Chunsky interfluve. The study provides lists of floristic finds collected in the Angaro-Chunsky interfluve at the settlements of Boguchany, Govorkovo, Manzya, and Osinovyi Mys in 2015-2016. The following species of flowering plants were found in the Chuno-Onsky floristic area for the first time: Carduus nutans L., Chamaerhodos erecta (L.) Bunge, Cynoglossum officinale L., Leonurus quinquelobatus Gilib., Linum perenne L., Lychnis sibirica L., Medicago lupulina L., Polygonum boreale (Lange) Small, Polygonum sabulosum Vorosch., Scutellaria scordiifolia Fisch. ex Schrank, and Solanum nigrum L. The species that are rare in this area were also found: Nuphar lutea (L.) Sm., Odontites vulgaris Moench, Polygonum rectum (Chrtek) Scholz. The coordinates, geographic points of plant collection, habitats, and dates of collecting are given for each species. The map of the study area with the positions of collection points is included. More accurate data have been obtained on the distribution and northern boundaries of the ranges of a number of species, confirming the available data on the ranges of these species in Middle Siberia.

Keywords: Angaro-Chunsky interfluve, Krasnoyarsk Krai, Boguchansky District, floristic finds.

(C) Siberian Federal University. All rights reserved

This work is licensed under a Creative Commons Attribution-NonCommercial 4.0 International License (CC BY-NC 4.0).

* Corresponding author E-mail address: garmaline@ro.ru 


\title{
Находки цветковых растений \\ в Ангаро-Чунском междуречье (Красноярский край) (2)
}

\author{
Ф.С. Юзефович, Н.Н. Тупицына \\ Красноярский государственньй \\ педагогический университет им. В.П. Астафьева \\ Россия, 660049, Красноярск, ул. Ады Лебедевой, 89
}

Ангаро-Чунское междуречье (Богучанский район Красноярского края) - отдаленная и в настоящее время недостаточно флористически изученная территория, которая находится в подзоне южной тайги Средней Сибири на границе трех флористических провинций (Алтае-Енисейской оро-гемибореальной, Тунгусско-Ленской бореальной, Байкальской гемибореальной) и занимает площадь около 20000 км². Гранищь района исследования: северная - левый берег р. Ангары, южная - правый берег р. Чуны, западная и восточная совпадают с административными границами Богучанского района. Активное хозяйственное освоение территории приводит $\kappa$ возрастанию антропогенной нагрузки, пожарам, что вызывает необходимость контроля состояния растительного покрова, организации мониторинга. Цель нашего исследования выявление состава, структуры и особенностей флоры Ангаро-Чунского междуречья. В статье приводится перечень флористических находок на территории Ангаро-Чунского междуречья, собранных в 2015-2016 гг. в окрестностях населенных пунктов: с. Богучаны, пос. Говорково, пос. Манзя, пос. Осиновый Мыс. Впервые на территории исследования найдены новые для ЧуноОнского флористического района виды иветковых растений: Carduus nutans L., Chamaerhodos erecta (L.) Bunge, Cynoglossum officinale L., Leonurus quinquelobatus Gilib., Linum perenne L., Lychnis sibirica L., Medicago lupulina L., Polygonum boreale (Lange) Small, Polygonum sabulosum Vorosch., Scutellaria scordiifolia Fisch. ex Schrank, Solanum nigrum L., a также редкие в этом районе виды: Nuphar lutea (L.) Sm., Odontites vulgaris Moench, Polygonum rectum (Chrtek) Scholz. Для каждого вида указываются координаты, географические пункты сбора, местообитания, даты сбора. Приведена карта района исследования с указанием пунктов сбора. Полученные данные позволяют уточнить распространение и северные гранищы ареалов ряда видов, подтверждаюшие имеютееся районирование на территории Средней Сибири.

Ключевые слова: Ангаро-Чунское междуречье, Красноярский край, Богучанский район, флористические находки. 


\section{Введение}

Территория Ангаро-Чунского междуречья находится в Чуно-Онском лесном флористическом районе (ФР) по районированию Красноярского края В.В. Ревердатто (Флора Красноярского края, 1960), в северо-восточной части Верхнеенисейского рабочего ФР Средней Сибири по рабочему флористическому районированию Л.И. Малышева (1987) и АлтаеЕнисейской оро-гемибореальной провинции (Malyshev et al., 2000), в подзоне южной тайги Средней Сибири (Любимова, 1964). Границы района: северная - левый берег р. Ангары, южная - правый берег р. Чуны, западная и восточная - административные границы Богучанского района. Исследуемый район мало изучен во флористическом отношении (Юзефович, Тупицына, 2015). В начале XX в. от состава экспедиции Переселенческого управления на водоразделе работал почвовед Н.В. Благовещенский (1910) вместе с И.М. Толмачевым, они оставили свои флористические сборы в Гербарии Ботанического института им. В.Л. Комарова (LE). В середине XX в., более 50 лет назад, собирая материал для «Флоры Красноярского края» (1960-1983), по рр. Чуне и Ангаре коллекционировали растения сотрудники Гербария Томского университета (ТК), а в междуречье трудились, сохранившие сведения о флоре в описаниях растительности, А.В. Белов, В.А. Ряшин (1965), геоботаники Института географии Сибири и Дальнего Востока СО АН СССР. Целенаправленное флористическое исследование в Ангаро-Чунском междуречье начато нами в 2015 г.

\section{Материалы и методы}

В 2015-2016 гг. выполнены полевые исследования в Ангаро-Чунском междуречье, часть результатов которых опубликована (Yuzefovich, Tupitsyna, 2016). Bce сборы осуществлены Ф.С. Юзефовичем (да- лее Ф.С.Ю.). Исследования велись методом конкретных флор, предложенным А.И. Толмачевым (1931), в сочетании с маршрутнорекогносцировочными обследованиями. Сбор материала проводился в разные сезоны года. Обработка материала осуществлялась по общепринятой методике (Корчагин, 1964). Указываются географические пункты, координаты, местообитания, обилие по О. Друде (Drude, 1890), даты сбора. Приведена карта района исследования (рис. 1). Цитируемые образцы хранятся в Гербарии им. Л.М. Черепнина (KRAS) Красноярского государственного педагогического университета им. В.П. Астафьева. Виды расположены в порядке латинского алфавита. Названия видов и авторы приводятся в соответствии с электронной базой данных по номенклатуре растений - http://www.ipni.org/ipni/ plantnamesearchpage.do.

\section{Результаты и обсуждение}

Выполненные исследования выявили новые виды и дополнительные местонахождения редких видов в Чуно-Онском ФР Красноярского края.

\section{Новые виды для Чуно-Онского ФР}

Carduus nutans L. (C. thoermeri Weinm.): «Красноярский край, Богучанский p-н, пос. Осиновый Мыс, правый берег р. Чуна, злаково-клеверовый прибрежный луг.

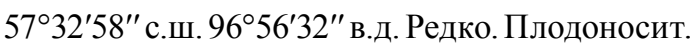
08 VI 2015. Ф. С. Ю.». - Распространен в Евразии, Северной Африке, заносный в Северной Америке (Жирова, 1997; Rauschert, Shea, 2017). Изредка встречается в степных и лесостепных районах края (Копанаева, 1980). Обнаруженное местонахождение самое северное в Средней Сибири, оторванное от основного ареала и, очевидно, заносное для вида. 


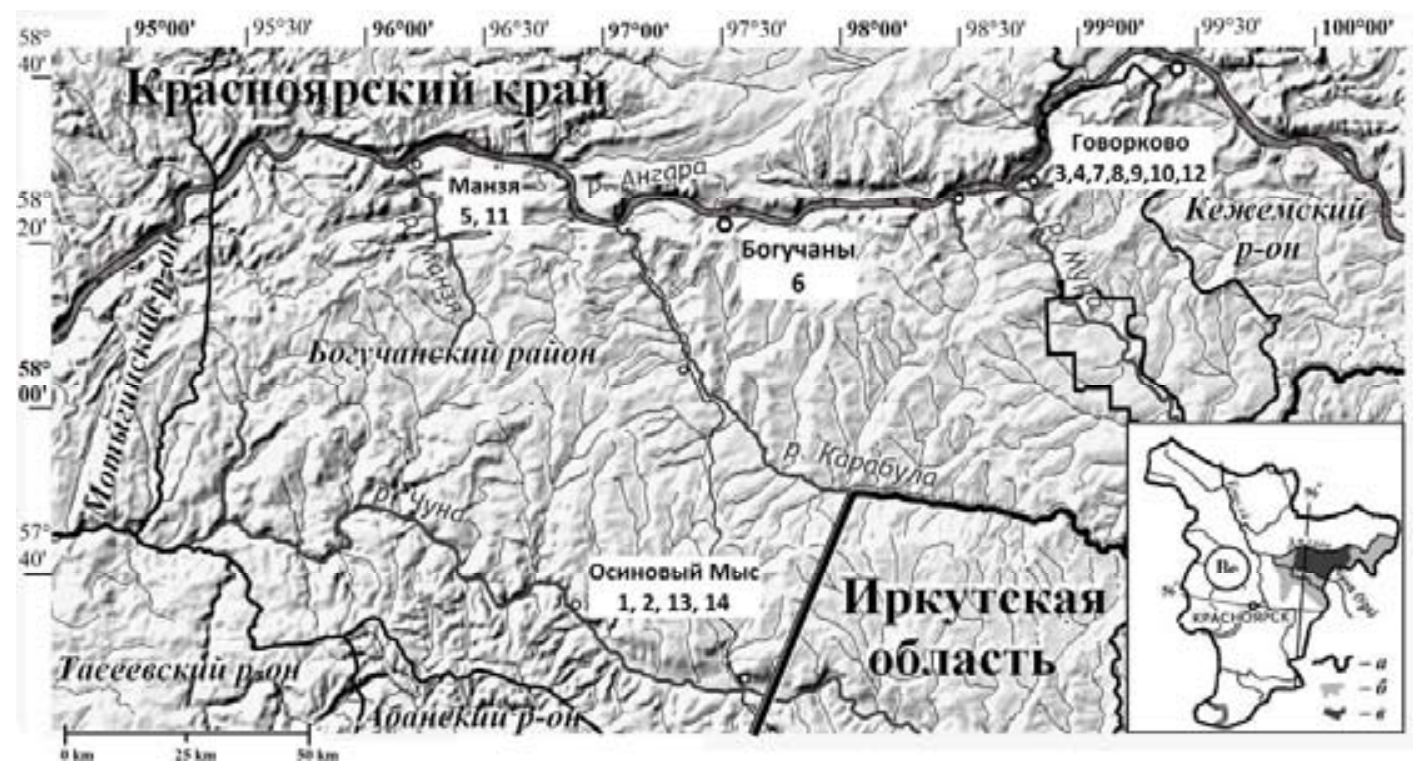

Рис. 1. Местонахождения видов в Ангаро-Чунском междуречье: 1 - Carduus nutans; 2 - Chamaerhodos erecta; 3 - Cynoglossum officinale; 4 - Leonurus quinquelobatus; 5 - Linum perenne; 6 - Lychnis sibirica; 7 Medicago lupulina; 8 - Nuphar lutea; 9 - Odontites vulgaris; 10 - Polygonum boreale; 11 - Polygonum rectum; 12 - Polygonum sabulosum; 13 - Scutellaria scordifolia; 14 - Solanum nigrum; $a$-граница Верхнеенисейского ФР; $\sigma$ - территория Чуно-Онского ФР; в - территория Ангаро-Чунского междуречья

Fig. 1. The location of the species in the Angaro-Chunsky interfluve: 1 -Carduus nutans; 2 -Chamaerhodos erecta; 3 - Cynoglossum officinale; 4 - Leonurus quinquelobatus; 5 - Linum perenne; 6 - Lychnis sibirica; 7 - Medicago lupulina; 8 - Nuphar lutea; 9 - Odontites vulgaris; 10 - Polygonum boreale; 11 - Polygonum rectum; 12 - Polygonum sabulosum; 13 - Scutellaria scordiifolia; 14 - Solanum nigrum; a - the boundary of the Verkhneyeniseiskiy floristic area; $\sigma$ - the territory of the Chuno-Onsky floristic area; $b$ - the territory of the Angaro-Chunsky interfluve

Chamaerhodos erecta (L.) Bunge: «Kpacноярский край, Богучанский р-н, 4 км западнее пос. Осиновый Мыс, правый берег р. Чуна, южный склон с выходящими наружу скалистыми обнажениями, молодой осиновоберезово-сосновый таволгово-разнотравный

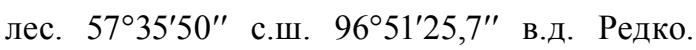
Цветет. 09 VI 2015. Ф. С. Ю.». - Произрастает в Сибири, Средней Азии, Монголии, на Дальнем Востоке, в Северном Китае (Выдрина, 1988). Распространен в степных и лесостепных районах края (Положий, Лошкарева, 1975). Как очень редкое растение указывается для подзоны южной тайги (Кетско-Чулымский ФР) (Ефиц, 1995). Наша находка - вторая в таежной зоне, на северной границе ареала.
Cynoglossum officinale L.: «Красноярский край, Богучанский р-н, восточная окраина пос. Говорково, обочина дороги, свалка. 58 $36^{\prime} 8^{\prime \prime}$ с.ш. 98 44'11" в.д. Изредка. Плодоносит. 03 VIII 2016. Ф. С. Ю.». - Ареал простирается в западной Палеарктике, занесен на Дальний Восток, в Северную Америку (Овчинникова, 1997; Runyon, Birdsall, 2016; Momayyezi, Upadhyaya, 2017). Встречается довольно часто в степных и лесостепных районах края, самое северное местонахождение было отмечено в Красноярской лесостепи (Положий, Копанаева, 1977). Найден в тайге C.C. Щербиной (Shherbina, 2009) (АнгароТунгусский ФР). Приводим второе таежное местонахождение (Чуно-Онский ФР), где, очевидно, обитает как заносное растение. 
Leonurus quinquelobatus Gilib.: «Красноярский край, Богучанский р-н, восточная окраина пос. Говорково, обочина дороги, свалка. $58^{\circ} 36^{\prime} 10^{\prime \prime}$ с.ш. $98^{\circ} 44^{\prime} 15^{\prime \prime}$ в.д. Изредка. Цветет. 03 VIII 2016. Ф. С. Ю.». - Распространен в Европе, на Кавказе, в Западной Азии, Сибири (Крестовская, 1997). Как очень редкое растение указан для Верхнеенисейского ФР - окр. г. Красноярска (Крестовская, 1997; Stepanov, Zavorokhina, 2000; Степанов, 2006), с. Агинское в Канской лесостепи (Антипова, 2012). Выявленное местонахождение крайне северное для вида, изолировано от основного ареала, очевидно заносное.

Linum perenne L.: «Красноярский край, Богучанский р-н, пос. Манзя, обочина дороги, злаковый луг. 58²9'58,7" с.ш. 96¹6'22,3" в.д. Единично. Цветет. 24 VII 2015. Ф. С. Ю.». - По данным Г.А. Пешковой (1996), произрастает в южных районах Сибири, в Европе, Казахстане и Малой Азии. Несмотря на то, что распространение вида в Сибири указано от Таймыра до Западного Саяна, в том числе вдоль p. Ангара, в Чуно-Онском ФР не был отмечен (Вылцан, 1977).

\section{Lychnis sibirica L.: «Красноярский} край, Богучанский р-н, 15 км западнее с. Богучаны, урочище «Абаканское», злаковотолокнянковое сообщество на просеке под ЛЭП в окружении соснового бора. 58 23'18" с.ш. 97¹1'30" в.д. Редко. Цветет. 22 VI 2016. Ф. С. Ю.». - Территория распространения охватывает Сибирь, Европу, Монголию, Дальний Восток (Зуев, 1993). Кроме степных и лесостепных районов края, где вид обычен (Гудошников, Колокольников, 1976), редко встречается также в подзонах южной и средней тайги (Ефиц, 1995; Shherbina, 2009). Отмеченное местонахождение дополняет инфор- мацию о распространении вида в северной части ареала.

Polygonum boreale (Lange) Small: «Кpacноярский край, Богучанский p-н, окраина пос. Говорково, опушка соснового леса. 5836'42" с.ш. 9843'25,3" в.д. Довольно обильно. Плодоносит. 01 VIII 2016. Ф. С. Ю.». - Распространен в Западной Сибири, на севере Европы, Дальнем Востоке, в Северной Америке (Тупицына, Кашина, 1992). В недавнее время вид найден в Средней Сибири в тундровой зоне Путоранского ФР (Tupitsyna, 2013; Tupitsyna, Lomonosova, 2016). Данная находка является первой для подзоны южной тайги и дополняет немногие известные местонахождения в Средней Сибири.

Polygonum sabulosum Vorosch.: «Красноярский край, Богучанский р-н, ЛЭП у р. Мура, неподалеку от устья, на дороге. $58^{\circ} 26^{\prime} 22^{\prime \prime}$ с.ш. 9833'56" в.д. Довольно обильно. Цветет и плодоносит. 12 VII 2016. Ф. С. Ю.». - Ареал вида занимает Восточную Сибирь, Дальний Восток и северо-восточную часть Китая (Тупицына, Кашина, 1992). Исследования последних лет выявили вид в Западной (Таран и др., 2004; Lashchinskiy et al., 2010; Tupitsyna et. al., 2013) и Средней Сибири, в том числе и в зоне тайги (Tupitsyna, 2013; Tupitsyna, Lomonosova, 2016), что подтверждает спорадическое распространение вида во всех районах Сибири.

Scutellaria scordiifolia Fisch. ex Schrank: «Красноярский край, Богучанский р-н, пос. Осиновый Мыс, берег р. Чуны, прибрежный разнотравный луг. 57³3'48" с.ш. 96 55'2" в.д. Редко. Цветет. 08 VII 2015. Ф. С. Ю.». - Произрастает в Южной Сибири, Монголии, Китае и на Дальнем Востоке (Зуев, 1997). Обычен во всех степных и лесостепных районах края, несколько местонахождений отмечено в лес- 
ной зоне, ближайшее к Чуно-Онскому ФР порог Стрелочный на р. Ангара (Быченникова, 1965). Наша находка уточняет северную границу распространения вида.

Solanum nigrum L.: «Красноярский край, Богучанский p-н, восточная окраина пос. Осиновый Мыс, северо-западная окраина аэродрома, разнотравный луг. 57³2'5.9" с.ш. 9656'32" в.д. Редко. Плодоносит. 08 VII 2015. Ф. С. Ю.». - Распространен в Европе, на Кавказе, в Средней и Малой Азии, в Сибири, Гималаях, Северо-Западном Китае, на Дальнем Востоке, указывается также для Восточной Азии и Северной Америки (Курбатский, 1996). Встречается изредка в степных и лесостепных районах края. Самое северное местонахождение находится в окр. д. Арефьева $\left(57^{\circ} 10^{\prime}\right)$ Кетско-Чулымского ФР (Курбатский, 1979). О.А. Ефиц (1995) в этом же ФР проводит северную границу распространения вида в крае. Наш пункт сбора расположен еще севернее.

Medicago lupulina L.: «Красноярский край, Богучанский р-н, окраина пос. Говорково, опушка соснового леса. 58³6'42" с.ш. $98^{\circ} 43^{\prime 2} 25,3^{\prime \prime}$ в.д. Изредка. Плодоносит. 01 VIII 2016. Ф. С. Ю.». - Занимает обширный ареал в Евразии, занесен в Северную Америку и Австралию (Курбатский, 1994). Произрастает в степных и лесостепных районах края, изредка заходит в лесную зону, где отмечалось самое северное местонахождение - с. Рыбное на р. Ангаре (58 с.ш.) (Положий, 1960). Позднее найден как заносное в Путоранском ФР (Курбатский, 1994). Наше местонахождение, очевидно, также заносное.

\section{Дополнительные местонахождения редких видов для Чуно-Онского ФР}

Nuphar lutea (L.) Sm.: «Красноярский край, Богучанский р-н, левый берег р. Мура, в воде. $58^{\circ} 22^{\prime} 41^{\prime \prime}$ с.ш. 98³8'32" в.д. Редко. Начало плодоношения. 06 VIII 2016. Ф. С. Ю.». Произрастает в южных районах Сибири, в Европе, на Кавказе, на территории Малой Азии и Северной Америки (Ковтонюк, 1993). Встречается, главным образом, в лесной и лесостепной зонах края. В.В. Ревердатто (1976) по данным А.И. Кытманова (1894) приводит вид для с. Богучан, ошибочно отнесенного к Ангаро-Тунгусскому ФР, поэтому зарегистрированное местонахождение второе в Чуно-Онском ФР.

Odontites vulgaris Moench: «Красноярский край, Богучанский р-н, окраина пос. Говорково, обочина дороги. 58 $36^{\prime} 10^{\prime \prime}$ с.ш. 9844'15" в.д. Редко. Цветет. 01 VIII 2016. Ф. С. Ю.». - Распространен в Евразии (Олонова, 1996). А.В. Положий (1979), давая распространение вида в степных и лесостепных районах края, приводит самое северное местонахождение в окр. с. Бокчер (58 Наша находка вторая достоверная в ЧуноОнском ФР, фиксирующая северную границу распространения вида.

Polygonum rectum (Chrtek) Scholz: «Красноярский край, Богучанский р-н, пос. Манзя, ул. Степана Мутовина, обочина дороги. 58 $29^{\prime} 47^{\prime \prime}$ с.ш. 96 $16^{\prime} 49^{\prime \prime}$ в.д. Довольно обильно. Цветет и плодонисит. 24 VII 2015. Ф. С. Ю.». - Как подвид (P. neglectum subsp. rectum (Chrtek.) Tzvel.) указан Н.Н. Цвелевым (1996) для Кавказа, Западной и Восточной Сибири, Дальнего Востока, Скандинавии, Атлантической и Средней Европы, Северной Америки; как вид им же (Цвелев, 2000, 2012) дается для европейской части страны, А.Л. Эбелем (Ebel, 2004) - для Хакасии. Конкретные местонахождения на юге Западной, Средней и Восточной Сибири регистрирует H.Н. Тупицына (Tupitsyna, 2011), она же при- 
водит единственный пункт сбора для ЧуноОнского ФР - с. Кежемское (Tupitsyna, 2013). Местонахождения в данном ФР самые северные для вида.

\section{Заключение}

Выявлено 11 новых видов и дополнительные местонахождения для трех редких видов в Чуно-Онском ФР. Полученные данные позволяют уточнить распространение видов на территории Красноярского края и Средней Сибири. Определены северные границы ареалов видов в Средней Сиби- ри: Chamaerhodos erecta, Lychnis sibirica, Scutellaria scordiifolia, Solanum nigrum, Odontites vulgaris. Концентрация видов на границе ареалов, как известно, служит индикатором рубежей флористических выделов, в данном случае подтверждающим близость северной границы Алтае-Енисейской оро-гемибореальной провинции и входящего в нее Верхнеенисейского ФР. Отмечен ряд заносных в южной тайге видов: Carduus nutans, Cynoglossum officinale, Leonurus quinquelobatus, Medicago lupulina, Polygonum rectum.

\section{Список литературы}

Антипова Е.М. (2012) Флора внутриконтинентальных островных лесостепей Средней Сибири. Красноярск, Краснояр. гос. пед. ун-т им. В.П. Астафьева, 662 с. [Antipova E.M. (2012) Flora of the inland island forest-steppes of Middle Siberia. Krasnoyarsk, V.P. Astafyev Krasnoyarsk State Pedagogical University, 662 p. (in Russian)]

Белов А.В., Ряшин В.А. (1965) Растительность левобережной части Нижнего Приангарья. Растительный покров Красноярского края. Bып. 2. Новосибирск, Наука, с. 165-178 [Belov A.V., Ryashin V.A. (1965) The vegetation of the left bank of the Lower Angara region. The vegetation cover of the Krasnoyarsk Krai. Vol. 2. Novosibirsk, Nauka, p. 165-178 (in Russian)]

Благовещенский Н.В. (1910) Описание почв Чуно-Ангарского водораздела в Енисейском районе. Материалы к исследованию колонизационных районов Азиатской России. Глинка К.Д. (ред.) СПб., Типография Ю.Н. Эрлих, с. 2-8 [Blagoveshchenskij N.V. (1910) Description of soils, Chuno-Angara watershed in the Yenisei region. Materials for the research of colonization regions in Asian Russia. Glinka K.D. (ed.) St. Petersburg, Yu.N. Ehrlih's Typography, p. 2-8 (in Russian)]

Быченникова Н.К. (1965) Сем. Губоцветные - Labiatae Juss. Флора Красноярского края. Bbin. 9. Томск, Изд-во Томск. ун-та, с. 141-172 [Bychennikova N.K. (1965) Labiatae Juss. Flora of the Krasnoyarsk region. Vol. 9. Tomsk, Tomsk State University, p. 141-172 (in Russian)]

Выдрина С.Н. (1988) Chamaerhodos Bunge - Хамеродос. Флора Сибири. T. 9. Новосибирск, Наука, с. 84-87 [Vydrina S.N. (1988) Chamaerhodos Bunge. Flora of Siberia. Vol. 9. Novosibirsk, Nauka, p. 84-87 (in Russian)]

Вылцан Н.Ф. (1977) Семейство Linaceae Льновые. Флора Красноярского края. Bып. 7. Томск, Изд-во Томск. ун-та, с. 8-9 [Vyltsan N.F. (1977) Linaceae. Flora of the Krasnoyarsk Krai. Vol. 7. Tomsk, Tomsk State University, p. 8-9 (in Russian)]

Гудошников С.В., Колокольников Л.Б. (1976) Семейство Caryophyllaceae Гвоздичные. Флора Красноярского края. Вылn. 5. Часть 3. Томск, Изд-во Томск. ун-та, с. 4-38 [Gudoshnikov S.V., Kolokolnikov L.B. (1976) Caryophyllaceae. Flora of the Krasnoyarsk Krai. Vol. 5. Part 3. Tomsk, Tomsk State University, p. 4-38 (in Russian)] 
Ефиц О.А. (1995) Флора южной части Енисейского района Красноярского края: автореф. дис. ... канд. биол. наук. Томск, Томский ун-т, 16 с. [Efits O.A. (1995) Flora of the southern part of the Yenisei district of the Krasnoyarsk Krai. Abstr. Cand. Diss. Tomsk, Tomsk State University, 16 p. (in Russian)]

Жирова О.С. (1997) Carduus L. - Чертополох. Флора Сибири. T. 13. Новосибирск, Наука, c. 210-211 [Zhirova O.S. (1997) Carduus L. - Thistle. Flora of Siberia. Vol. 13. Novosibirsk, Nauka, p. 210-211 (in Russian)]

Зуев В.В. (1993) Lychnis L. - Зорька. Флора Сибири. T. 6. Новосибирск, Наука, с. 58-59 [Zuev V.V. (1993) Lychnis L. Flora of Siberia. Vol. 6. Novosibirsk, Nauka, p. 58-59 (in Russian)]

Зуев B.B. (1997) Scutellaria L. - Шлемник. Флора Сибири. T. 11. Новосибирск, Наука, c. 161-165 [Zuev V.V. (1997) Scutellaria L - Skullcap. Flora of Siberia. Vol. 11. Novosibirsk, Nauka, p. 161-165 (in Russian)]

Ковтонюк Н.К. (1993) Семейство Nymphaeaceae - Кувшинковые. Флора Сибири. T. 11. Новосибирск, Наука, с. 95-96 [Kovtonyuk N.K. (1993) Nymphaeaceae. Flora of Siberia. Vol. 11. Novosibirsk, Nauka, p. 95-96 (in Russian)]

Копанаева Г.А. (1980) Carduus L. Чертополох. Флора Красноярского края. Bыn. 10. Томск, Изд-во Томск. ун-та, с. 87 [Kopanaeva G.A. (1980) Carduus L. Thistle. Flora of the Krasnoyarsk Krai. Vol. 10. Tomsk, Tomsk State University, p. 87 (in Russian)]

Корчагин А.А. (1964) Видовой (флористический) состав растительных сообществ и методы его изучения. Полевая геоботаника. T. 3. Москва, Наука, с. 39-62 [Korchagin A.A. (1964) Species (floristic) composition of plant communities and methods of research. Field Geobotany. Vol. 3. Moscow, Nauka, p. 39-62 (in Russian)]

Крестовская Т.В. (1997) Leonurus L. - Пустырник. Флора Сибири. T. 11. Новосибирск, Наука, с. 192-195 [Krestovskaya T.V. (1997) Leonurus L. - Motherwort. Flora of Siberia. Vol. 11. Novosibirsk, Nauka, p. 95-96 (in Russian)]

Курбатский В.И. (1979) Семейство Solanaceae - Пасленовые. Флора Красноярского края. Bыn. 9. Часть 2. Томск, Изд-во Томск. ун-та, с. 3-4 [Kurbatskiy V.I. (1979) Solanaceae. Flora of the Krasnoyarsk Krai. Vol. 9. Part 2. Tomsk, Tomsk State University, p. 3-4 (in Russian)]

Курбатский В.И. (1994) Medicago L. - Люцерна. Флора Сибири. T. 9. Новосибирск, Наука, c. 196-199 [Kurbatskiy V.I. (1994) Medicago L. - Medic. Flora of Siberia. Vol. 9. Novosibirsk, Nauka, p. 196-199 (in Russian)]

Курбатский В.И. (1996) Семейство Solanaceae - Пасленовые. Флора Сибири. T. 12. Новосибирск, Наука, с. 8-12 [Kurbatskiy V.I. (1996) Solanaceae. Flora of Siberia. Vol. 12. Novosibirsk, Nauka, p. 8-12 (in Russian)]

Кытманов А.И. (1894) Материаль для флоры сосудистых растений Енисейского округа Енисейской губернии. Томск, Типо-Литография П.И. Макушина, 68 с. [Kytmanov A.I. (1984) Materials for the flora of vascular plants of the Yenisei district of the Yenisei province. Tomsk, P.I. Makushin's Typo-Lithography, 68 p. (in Russian)]

Любимова Е.Л. (1964) Растительный покров. Средняя Сибирь. М., Наука, с. 226-276 [Lyubimova E.L. (1964) Vegetable cover. Middle Siberia. Moscow, Nauka, p. 226-276 (in Russian)]

Малышев Л.И. (1987) Предисловие. Флора Сибири. T. 4. Новосибирск, Наука, с. 5-12 [Malyshev L.I. (1988) Preface. Flora of Siberia. Vol. 4. Novosibirsk, Nauka, p. 5-12 (in Russian)] 
Овчинникова С.В. (1997) Cynoglossum L. - Чернокорень. Флора Сибири. T. 11. Новосибирск, Наука, с. 156 [Ovchinnikova S.V. (1997) Cynoglossum L. - Hound's-tongue. Flora of Siberia. Vol. 11. Novosibirsk, Nauka, p. 156 (in Russian)]

Олонова М.В. (1996) Odontites Ludwig - Зубчатка. Флора Сибири. T. 12. Новосибирск, Наука, с. 62-63 [Olonova M.V. (1996) Odontites Ludwig - Bartsia. Flora of Siberia. Vol. 12. Novosibirsk, Nauka, p. 62-63 (in Russian)]

Пешкова Г.А. (1996) Семейство Linaceae - Льновые. Флора Сибири. T. 10. Новосибирск, Наука, с. 23-29 [Peshkova G.A. (1996) Linaceae. Flora of Siberia. Vol. 10. Novosibirsk, Nauka, p. 23-29 (in Russian)]

Положий А.В. (1960) Семейство Papilionaceae. Флора Красноярского края. Bып. 6. Томск, Изд-во Томск. ун-та, с. 20-41 [Polozhiy A.V. (1960) Papilionaceae. Flora of the Krasnoyarsk Krai. Vol. 6. Tomsk, Tomsk State University, p. 20-41 (in Russian)]

Положий А.В., Копанаева Г.А. (1977) Семейство Boraginaceae Бурачниковые. Флора Красноярского края. Bыл. 8. Томск, Изд-во Томск. ун-та, с. 113-127 [Polozhiy A.V., Kopanaeva G.A. (1975) Boraginaceae. Flora of the Krasnoyarsk Krai. Vol. 8. Tomsk, Tomsk State University, p. 113127 (in Russian)]

Положий А.В. (1979) Семейство Scrophulariaceae Норичниковые. Флора Красноярского края. Bып. 9. Часть 2. Томск, Изд-во Томск. ун-та, с. 4-36 [Polozhiy A.V. (1979) Scrophulariaceae. Flora of the Krasnoyarsk Krai. Vol. 9. Part 2. Tomsk, Tomsk State University, p. 4-36 (in Russian)]

Положий А.В., Лошкарева Л.Н. (1975) Семейство Rosaceae Розоцветные. Флора Красноярского края. Bылn. 5. Часть 4. Томск, Изд-во Томск. ун-та, с. 88-141 [Polozhiy A.V., Loshkareva L.N. (1975) Rosaceae. Flora of the Krasnoyarsk Krai. Vol. 5. Part 4. Tomsk, Tomsk State University, p. 88141 (in Russian)]

Ревердатто В.В. (1976) Семейство Nурhаеасеае Кувшинковые. Флора Красноярского края. Bbin. 5. Часть 3. Томск, Изд-во Томск. ун-та, с. 38-40 [Reverdatto V.V. (1976) Nyphaeaceae. Flora of the Krasnoyarsk Krai. Vol. 5. Part 3. Tomsk, Tomsk State University, p. 38-40 (in Russian)]

Степанов Н.В. (2006) Флора северо-востока Западного Саяна и острова Отдыха на Енисее (2. Красноярск). Красноярск, Краснояр. гос. ун-т, 170 с. [Stepanov N.V. Flora of the NorthEast of the Western Sayan Mountains and Otdykh Island in the Yenisei (Krasnoyarsk). Krasnoyarsk, Krasnoyarsk State University, 170 p. (in Russian)]

Таран Г.С., Седельникова Н.В., Писаренко О.Ю., Голомолзин В.В. (2004) Флора и растительность Елизаровского государственного заказника: (Нижняя Объ). Новосибирск, Наука, 212 c. [Taran G.S., Sedelnikova N.V., Pisarenko O.Y., Golomolzin V.V. Flora and vegetation of the Elizarovskiy State Reserve: (the Lower Ob River). Novosibirsk, Nauka, 212 p. (in Russian)]

Толмачев А.И. (1931) К методике сравнительно-флористических исследований. 1. Понятие о флоре в сравнительной флористике. Журнал Русского ботанического общества, 16(11): 111-124 [Tolmachev A.I. (1931) On the methods of comparative floristic studies. 1. On the term "flora" in comparative floristics. Journal of the Russian Botanical Society [Zhurnal Russkogo botanicheskogo obshchestva], 16(11): 111-124 (in Russian)]

Тупицына Н.Н., Кашина Л.И. (1992) Polygonaceae - Гречишные. Флора Сибири. Т. 5. Новосибирск, Наука, с. 87-135 [Tupitsyna N.N., Kashina L.I. (1992) Polygonum L. - Knotweed. Flora of Siberia. Vol. 11. Novosibirsk, Nauka, p. 87-135 (in Russian)] 
Флора Красноярского края (1960-1983) Bыn. 1-10. Томск, Изд-во Томск. ун-та [Flora of the Krasnoyarsk Krai. (1960-1983) Vol. 1-10. Tomsk, Tomsk State University (in Russian)]

Цвелев Н.Н. (1996) Род спорыш - Polygonum L. Флора Восточной Европьл. T. 9. СПб, Издво Мир и семья-95, с. 136-150 [Tzvelev N.N. (1996) Knotweed - Polygonum L. Flora of Eastern Europe. Vol. 9. St. Petersburg, Mir i semya-95, p. 136-150 (in Russian)]

Цвелев Н.Н. (2000) Определитель сосудистых растений северо-западной России (Ленинградская, Псковская и Новгородская области). СПб., Изд-во СПХФА, 781 с. [Tzvelev N.N. (2000) Identification key for the vascular plants of North-West Russia (Leningrad, Pskov and Novgorod Oblasts). St. Petersburg, Saint-Petersburg State Chemical Pharmaceutical Academy, 781 p. (in Russian)]

Цвелев Н.Н. (2012) Род Polygonum L. Конспект флоры Восточной Европы. T.1. СПб.-М., Товарищество научных изданий КМК, с. 323-329 [Tzvelev N.N. (2012) Polygonum L. Synopsis of the flora of Eastern Europe. Vol. 1. St. Petersburg, Moscow, KMK Scientific Press Ltd., p. 323-329 (in Russian)]

Юзефович Ф.С., Тупицына Н.Н. (2015) История исследования растительного покрова Ангаро-Чунского междуречья (Богучанский район Красноярского края). Проблемы ботаники Южной Сибири и Монголии. Сборник научных статей по материалам Четырнадиатой международной научно-практической конферениии (Барнаул, 25-29 мая 2015 г.). Барнаул, Издательство Алтайского государственного университета, с. 121-124 [Yuzefovich F.S., Tupitsyna N.N. (2015) The history of the research of vegetation cover in the Angaro-Chunsky interfluve (the Boguchansky District of the Krasnoyarsk Krai). Problems of Botany of South Siberia and Mongolia. Proceedings of the $14^{\text {th }}$ International Scientific and Practical Conference (Barnaul, 25-29 May 2015). Barnaul, Altai State University, p. 121-124 (in Russian)]

Drude O. (1890) Handbuch der pflanzengeographie. Stuttgart, J. Engelhorn Verlag

Ebel A.L. (2004) About distribution of the Polygonaceae Juss. species in Khakasia. Systematic notes on the materials of P.N. Krylov Herbarium of Tomsk State University, 94: 12-16 (in Russian)

Lashchinskiy N.N., Korolyuk A.Ju., Lashchinskaya N.V., Korolyuk E.A. (2010) New records of rare and invasive vascular plant species from Omsk, Novosibirsk, Tumen and Altai areas. Turczaninowia, 13(1): 117-123 (in Russian)

Malyshev L.I., Baikov K.S., Doronkin V.M. (2000) Floristic division of Asiatic Russia on the basis of quantitative data. Krylovia, 2(1): 3-16 (in Russian)

Momayyezi M., Upadhyaya M.K. (2017) Influence of soil moisture stress on vegetative growth and mycorrhizal colonization in hound's-tongue (Cynoglossum officinale). Weed Science, 65(1): 107-114

Rauschert E.S.J., Shea K. (2017) Competition between similar invasive species: modeling invasional interference across a landscape. Population Ecology, 59(1): 79-88

Runyon J.B., Birdsall J.L. (2016) Costs of induced defenses for the invasive plant houndstongue (Cynoglossum officinale L.) and the potential importance for weed biocontrol. Arthropod-Plant Interactions, 10(5): 383-391

Shherbina S.S. (2009) Flora of vascular plants of Central Siberian state biospheric reserve and neighboring territories. Turczaninowia, 12 (1-2): 71-241 (in Russian) 
Stepanov N.V., Zavorokhina M.V. (2000) On the records of rare and new to Krasnoyarsk region vascular plants species. Bulletin of Moscow Society of Naturalists. Biological Series, 105 (2): 56 (in Russian)

Tupitsyna N.N. (2011) Addition to the Flora of Siberia (Polygonaceae Juss.). Turczaninowia. 14 (1): 55-58 (in Russian)

Tupitsyna N.N. (2013) Addition to the Krasnoyarsk region flora (Polygonum L., Polygonaceae Juss.). Bulletin of KrasGAU, 2: 36-39 (in Russian)

Tupitsyna N.N., Hozyainova N.V., Kuzmin I.V. (2013) Knotgrasses (Polygonum L., Polygonaceae Juss.) of Tyumen province. Turczaninowia, 16(3): 78-83 (in Russian)

Tupitsyna N.N., Lomonosova M.L. (2016) New data on knotweeds (Polygonum L., Polygonaceae) in the flora of the northern part of Krasnoyarsk krai. Bulletin of Moscow Society of Naturalists. Biological Series, 121(3): 78-79 (in Russian)

Yuzefovich F.S., Tupitsyna N.N. (2016) New findings of flowering plants in Angaro-Chunsky interfluve (Krasnoyarsk region). Turczaninowia, 19 (3): 68-72 (in Russian) 